\title{
TRAFFIC FLOW MODEL BASED ON CELLULAR AUTOMATION WITH ADAPTIVE DECELERATION
}

\author{
A.A. Shinkarev, sania.kill@mail.ru \\ "741 Studios.ru" LLC, Ekaterinburg, Russian Federation
}

\begin{abstract}
This paper describes continuation of the authors' work in the field of traffic flow mathematical models based on the cellular automata theory. The refactored representation of the multifactorial traffic flow model based on the cellular automata theory is used for a representation of an adaptive deceleration step implementation. The adaptive deceleration step in the case of a leader deceleration allows slowing down smoothly but not instantly. Concepts of the number of time steps without conflicts and deceleration aggressiveness coefficient are introduced. Also in this paper a new step type for models based on the cellular automata is formulated on the example of a stop signal. The new step type unites notification and signalization steps. The new step type extends the concept of the three-stepped unified representation of the traffic flow models based on the cellular automata that was formulated in the previous authors' work.
\end{abstract}

Keywords: modeling, traffic flow, cellular automata, traffic, adaptive deceleration, formalization.

\section{Introduction}

In the paper [1] the three-stepped unified representation of the traffic flow models based on the cellular automata was introduced. This unified representation included three step types of the cellular automata work: velocity changing, validation and driving. The last step is always the driving step. Before this step there could be any number of velocity changing and the result velocity validation steps.

In the paper [2] the way how the refactoring approach could be applied for several cellular automata traffic flow models was demonstrated. The goal of such refactoring was a unification of these models representation. In particular the multifactorial model representation that is described in the work [3] was reformed. The work algorithm of this model is much easier to analyze for the refactored representation than for the original one. This simplified analysis allows to identify steps which behavior could be improved to achieve more realistic results of the modeling process.

\section{Model Environment and Notations}

Let's assume that we have a two-dimensional matrix $L$, which consists of cells with a fixed length. $M$ and $N$ parameters determine the height (lanes number) and the weight (road length) of the matrix respectively. At any given moment of time each cell can be empty or occupied by a vehicle. Each vehicle length could vary and be more or equal to one cell.

Time $t$ is a discrete quantity and has a step that equals to 1 second that is approximately a reaction time of an average driver. The $i$ vehicle position determines by $m_{i}$ и $n_{i}$ variables where $m_{i}$ is the traffic lane and $n_{i}$ is the cell number on that traffic lane.

Velocity $v_{i}$ is measured in cells passed during the time step which is 1 second.

Hereinafter in the article the following notations are used:

$t$ - current time step of the automaton work;

$t-1$ - previous time step of the automaton work;

$v_{i}$ - returns velocity of the $i$ vehicle;

$g_{i}-$ returns distance from the $i$ vehicle to the leader;

$v_{\max }$ - maximally allowed velocity of the vehicles;

$v_{l \max _{i}}-$ velocity that is maximally allowed by a Rules of the Road;

$v_{m}\left(c_{i}\right)$ - maximum velocity of the vehicle that is limited by its technical characteristics;

$v_{\text {rec }_{i}}-$ recommended velocity according to the vehicle position;

$\xi$ - random value that is distributed equally; 
$p_{\text {sts }}$ - probability of the slow-to-start rule triggering;

$d_{s t s}$ - limit distance when the slow-to-start rule is still applicably;

$p_{s a}$ - probability of the spatial anticipation rule triggering;

$d_{s a}$ - limit distance when the spatial anticipation rule is still applicably;

$b_{i}-$ sign that the stop-light is on;

$S S A$ - determines if a full stop of the vehicles is allowed.

\section{Transition to Adaptive Deceleration Step}

\subsection{Original Model Representation}

Let's list the representation of the multifactorial model that was obtained in the paper [2].

1. Acceleration

if $\xi(t)<p_{s t s}$ and $v_{i}(t-1)=0$ and $g_{i}(t-1) \leq d_{s t s}$,

then $v_{i}(t)=0$,

else $v_{i}(t)=v_{i}(t-1)+1$.

2. Deceleration

$b_{i}(t)=0$,

if $\xi(t)<p_{s a}$ and $v_{i}(t-1)>0$ and $v_{i+1}(t-1)>0$ and $g_{i}(t-1) \leq d_{s a}$

and $\left(b_{i+1}(t-1)=1\right.$ or $\left.v_{i+1}(t-1)<v_{i}(t-1)\right)$,

then $v_{i}(t)=v_{i+1}(t-1), b_{i}(t)=1$,

if $v_{i}(t)>g_{i}(t-1)$ then $b_{i}(t)=1$.

3. Random deceleration

if $\xi(t)<p$ then $v_{i}(t)=v_{i}(t)-1$.

4. Validation of the recommended and the maximally allowed by the Rules of the Road velocities exceeding

$v_{i}(t)=\min \left(v_{i}(t), v_{l \max _{i}}(t-1), v_{\text {rec }_{i}}(t-1)\right)$.

5. Velocity exceeding

if $\xi(t)<p_{s}$ and $v_{i}(t-1)=v_{l \max _{i}}(t-1)$,

then $v_{i}(t)=v_{i}(t-1)+1$.

6 . Validation of the maximally allowed velocity exceeding

$v_{i}(t)=\min \left(v_{i}(t), v_{\max }, v_{m}\left(c_{i}\right)\right)$.

7. Validation of the negative velocity

if $v_{i}(t)<0$ then $v_{i}(t)=0$.

8 . Validation of the full stop

if $v_{i}(t)=0$ and $S S A=F$ then $v_{i}(t)=1$.

9. Validation of the leader vehicle impact

if $v_{i}(t)>g_{i}(t-1)$ then $v_{i}(t)=g_{i}(t-1)$.

10. Driving

$n_{i}(t)=n_{i}(t-1)+v_{i}(t)$.

The represented model aggregates the classical unidirectional multilane driving model, the slow-tostart rule [4], the spatial anticipation rule [5], random velocity exceeding and also limits of the maximum velocity $\left(v_{\max }, v_{\text {max }_{i}}, v_{m}\left(c_{i}\right), v_{\text {rec }_{i}}\right)$.

\subsection{Introduction of Adaptive Deceleration Step}

Considerable disadvantage of this model is the deceleration step. The main reason of this is the fact that the velocity deceleration to the leader velocity occurs instantly and only within the $d_{s a}$ distance.

Also it's possible that the next vehicle decreased its velocity but it's still faster than the $i$ vehicle and in this case we would have unwanted velocity adaptation up to the next vehicle velocity with $b_{i}$ signal on.

Formally this model uses the stop signal $b_{i}$, but actually it isn't the classical stop signal during a deceleration. It's in some way an analog which for this model signalized about the velocity adaptation up to the next vehicle velocity.

In this particular situation it seems efficient and not so difficult to modernize this model by a revision of the deceleration step. The main task here is the implementation of an adequate deceleration in 


\section{Краткие сообщения}

response to the leader vehicle stop signal. From the real traffic point of view it would be an analog of the progressive deceleration with the smooth distance decreasing to the leader vehicle.

Let's introduce a notation $v_{d i f_{i}}$, which would denote the velocities difference between the $i$ vehicle and the next vehicle.

$v_{\text {dif }}=v_{i}(t)-v_{i+1}(t)$.

To be able to calculate the number of the time steps for which the leader vehicle impact is impossible we need to divide the distance to the leader $g_{i}$ on the velocities difference $v_{\text {dif }_{i}}$ and round it down. Let's introduce a function $Z_{i}$, which returns the number of time steps without conflicts.

$Z_{i}=\left\lfloor\frac{g_{i}(t)}{v_{\text {dif }_{i}}(t)}\right\rfloor$.

Now when we know the distance to the leader $v_{d i f_{i}}$, the number of time steps without conflicts $Z_{i}$ and the fact that the current velocity won't be changed we can calculate how much should we decrease the velocity in the current time step to be able to decrease the velocity up to the leader one for the $Z_{i}$ time steps. This velocity deceleration could be calculated as a relation of the velocities difference $v_{\text {dif }}(t-1)$ to the number of time steps without conflicts $Z_{i}(t-1)$.

$\frac{v_{\text {dif }}(t-1)}{Z_{i}(t-1)}$.

Thus velocity changing for the deceleration step could be formulated in the following way:

$v_{i}(t)=v_{i}(t-1)-\left\lceil\frac{v_{d i f_{i}}(t-1)}{Z_{i}(t-1)} K_{a g r}\right\rceil$.

In this case $K_{a g r}$ is the coefficient of the deceleration aggressiveness.

As a whole now the deceleration step would be formulated in the following way:

if $\xi(t)<p_{s a}$ and $g_{i}(t-1) \leq d_{s a}$ and $\left(b_{i+1}(t-1)=1\right.$

or $\left.v_{\text {dif }}(t-1)>0\right)$ and $0<Z_{i}(t-1)<Z_{\text {upper }}$,

then $v_{i}(t)=v_{i}(t-1)-\left\lceil\frac{v_{d i f_{i}}(t-1)}{Z_{i}(t-1)} K_{a g r}\right\rceil$.

In this case $Z_{\text {upper }}$ is the upper limit of the number of time steps without conflicts above which the deceleration is devoid of sense.

Besides changing of the new velocity formula as a reaction on the leader deceleration redundant checks of non-zero velocities were removed.

Now we need to notify the vehicle behind about the fact that the velocity was decreased comparing to the previous time step.

Let's add a new notification step that would signal that the stop signal is on:

if $v_{i}(t)<v_{i}(t-1)$,

then $b_{i}(t)=1$,

else $b_{i}(t)=0$.

On the example of this step which in fact notify other drivers about the velocity decreasing there could be introduced a new common step type for the traffic flow models based on the cellular automata theory. The new step type unites notification and signalization steps which could be used for information exchange modeling among the motoring public. In this paper the stop signal notification step represented. Also it seems viable to investigate a possibility of performing notifications about the intention to change the traffic lane and waiting for a response from other vehicles.

As the result of the new step type introduction the three-stepped unified representation of the cellular automata traffic flow models is transformed to the four-stepped one. The result steps list would be the following: velocity changing, validation, notification and driving.

\section{Conclusion}

In this article on the example of the refactored representation of the unidirectional multilane multifactorial traffic flow model the deceleration step was completely refined. The number of time steps without conflicts $Z_{i}$ and the coefficient of the deceleration aggressiveness $K_{\text {agr }}$ were introduced. Also the formula (14) was introduced. This formula allows to decrease the velocity smoothly in the response to the deceleration of the leader but only within the decision making interval. The response velocity de- 
celeration has a stochastic nature and it won't be made at all if there are enough time steps without conflicts according to the $Z_{\text {upper }}$ parameter.

Besides the deceleration step logic changing the $b_{i}$ signal meaning was changed. In particular the transition from the pseudo stop signal modeling to the real one was made. Also the reaction on the stop signal was modeled.

On the example of the stop signal the new fourth step type was added to the unified representation of the traffic flow models based on the cellular automata. It is the notification (signalization) step type.

\title{
References
}

1. Shinkarev A.A. [Three-stepped Unified Representation of Traffic Flow Models Based on Cellular Automaton]. International Research Journal, 2015, no. 3(34), pp. 126-128. (in Russ.)

2. Shinkarev A.A. [Analysis and Refactoring of Representation of Traffic Flow Models Based on Cellular Automaton]. In the World of Scientific Discoveries, 2015, no. 4.1(64), pp. 585-595. (in Russ.)

3. Dolgushin D.Yu. Primenenie kletochnykh avtomatov $k$ modelirovaniyu avtotransportnykh potokov [Appliance of cellular automata in traffic flow modeling]. Available at: http://bek.sibadi.org/fulltext/ epd624.pdf (accessed 01.08.2015).

4. Takayasu M., Takayasu H. 1/f Noise in a Traffic Model. Fractals, 1993, vol. 4, no. 1, pp. 860866.

5. Knospe W., Santen L., Schadschneider A., Schreckenberg M. Towards a Realistic Microscopic Description of Highway Traffic. J. Phys. A: Math. Gen., 2000, no. 33, pp. 477-485.

Received 25 December 2015

Удк 62:004.942:004.4

DOI: $10.14529 /$ ctcr160115

\section{МОДЕЛЬ ТРАНСПОРТНЫХ ПОТОКОВ НА ОСНОВЕ КЛЕТОЧНОГО АВТОМАТА С АДАПТИВНЫМ ТОРМОЖЕНИЕМ}

\author{
А.А. Шинкарев \\ ООО «741 Студиос.ру», г. Екатеринбург
}

\begin{abstract}
Рассмотрено продолжение работы автора в области математических моделей транспортных потоков на основе теории клеточных автоматов. На примере переработанного представления многофакторной модели транспортных потоков на основе теории клеточных автоматов представлена реализация шага адаптивного торможения, который в случае торможения впереди едущего транспортного средства позволяет снижать скорость плавно, а не мгновенно. Введены понятия количества тактов без конфликта и коэффициента агрессивности торможения. Также в статье на примере стоп-сигнала сформулирован новый тип шагов для моделей на основе клеточного автомата, который объединяет шаги оповещения и сигнализации. Новый тип шагов расширяет концепцию трёхступенчатого унифицированного представления математических моделей транспортных потоков на основе клеточного автомата, которая была сформулирована в предыдущей работе автора.

Ключевые слова: моделирование, транспортный поток, клеточный автомат, дорожное движение, адаптивное торможение, формализация.
\end{abstract}

\section{Лuтература}

1. Шинкарев, А.А. Трехступенчатое унифицированное представление моделей транспортных потоков на основе клеточного автомата / А.А. Шинкарев // Международный научноисследовательский журнал. - 2015. - № 3(34). - С. 126-128. 


\section{Краткие сообщения}

2. Шинкарев, А.А. Анализ и рефакторинг представления моделей транспортных потоков на основе клеточного автомата / А.А. Шинкарев // В мире научных открытий. - 2015. - № 4.1(64). C. $585-595$

3. Долгушин, Д.Ю. Применение клеточных автоматов к моделированию автотранспортных потоков / Д.Ю. Долгушин. - http://bek.sibadi.org/fulltext/epd624.pdf (дата обращения 01.08.2015).

4. Takayasu, M. 1/f Noise in a Traffic Model / M. Takayasu, H. Takayasu // Fractals. - 1993. - Vol. 4, no. 1. - P. 860-866.

5. Towards a Realistic Microscopic Description of Highway Traffic / W. Knospe, L. Santen, A. Schadschneider, M. Schreckenberg // J. Phys. A: Math. Gen. - 2000. - No. 33. - P. 477-485.

Шинкарев Александр Андреевич, инженер-программист, ООО «741 Студиос.ру», г. Екатеринбург; sania.kill@mail.ru.

Поступила в редакцию 25 декабря 2015 г.

\section{ОБРАЗЕЦ ЦИТИРОВАНИЯ}

Shinkarev A.A. Traffic Flow Model Based on Cellular Automation with Adaptive Deceleration / A.A. Shinkarev // Вестник ЮУрГУ. Серия «Компьютерные технологии, управление, радиоэлектроника». - 2016. T. 16, № 1. - C. 160-164. DOI: 10.14529/ctcr160115

\section{FOR CITATION}

Shinkarev A.A. Traffic Flow Model Based on Cellular Automation with Adaptive Deceleration. Bulletin of the South Ural State University. Ser. Computer Technologies, Automatic Control, Radio Electronics, 2015, vol. 16, no. 1, pp. 160-164. DOI: 10.14529/ctcr160115 